14 - ORIGINAL ARTICLE

Ischemia-Reperfusion

\title{
The influence of methylene blue on the healing of intestinal anastomoses subjected to ischemia and reperfusion in rats $^{1}$
}

\author{
A influência do azul de metileno na cicatrização de anastomoses intestinais submetidas à \\ isquemia e reperfusão em ratos
}

\author{
Eron Fabio Miranda ${ }^{\mathrm{I}}$, Fernando Hintz Greca ${ }^{\mathrm{II}}$, Lucia Noronha ${ }^{\mathrm{III}}$, Luiz Roberto Kotze ${ }^{\mathrm{IV}}$, Michel Risnic Rubin ${ }^{\mathrm{V}}$ \\ I Fellow Master Degree, Post-Graduate Program of Surgery, PUC-PR, Paraná, Brazil. \\ ${ }^{\text {II }}$ Full Professor, Experimental Surgery, PUC-PR, Paraná, Brazil. \\ III Full Professor, Pathology Department, PUC-PR, Paraná, Brazil. \\ ${ }^{\text {Iv }}$ MD, Resident of Pathology Department, Federal University of Paraná, Brazil. \\ ${ }^{v}$ Graduate student, Medical School, PUC-PR, Paraná, Brazil
}

\begin{abstract}
Purpose: To investigate the influence of methylene blue, on the healing of intestinal anastomoses subjected to ischemia and reperfusion in rats. Methods: Forty-five rats divided into the following three groups were used: control (G1); ischemia without methylene blue (G2); and ischemia with methylene blue (G3). A laparotomy was performed and the cranial mesenteric artery isolated. Whereas the cranial artery was temporarily occluded for 45 minutes in groups G2 and G3, prior to enterotomy and intestinal anastomosis, in group G1 the enterotomy and intestinal anastomosis were performed without prior lesion. Afterwards, $2 \mathrm{~mL}$ of $0.5 \%$ methylene blue were instilled in the peritoneal cavities of the animals in group $\mathrm{G} 3$, and $2 \mathrm{~mL}$ of isotonic saline solution in the peritoneal cavities of the animals in group G2. After the reperfusion, an enterectomy and intestinal anastomosis were performed. After the animals had been sacrificed on the seventh day after the operation, the abdominal cavity was examined by resection of a segment of the intestine containing the anastomosis in order to measure its strength and for histopathological examination. Results: Free fluid or abscesses in the peritoneal cavity were rare. When inflammation was analyzed, the group subjected to ischemia without methylene blue had a higher score for mononuclear cells $(\mathrm{p}=0.021)$ and granulation tissue $(\mathrm{p}=0.044)$. No significant difference was observed in the density of type I or type III collagens. Conclusion: The methylene blue did not show beneficial effect on the healing of intestinal anastomoses subjected to ischemia and reperfusion in rats.
\end{abstract}

Key words: Anastomosis, Surgical. Wound Healing. Ischemia. Small Intestine. Reperfusion Injury. Methylene Blue. Rats.

\section{RESUMO}

Objetivo: Investigar a influência do azul de metileno, na cicatrização de anastomoses intestinais de ratos submetidas a isquemia e à reperfusão. Métodos: Quarenta e cinco ratos foram divididos em três grupos: controle (G1); isquemia sem azul de metileno (G2) e isquemia com azul de metileno (G3). Foi feita uma laparotomia e a artéria mesentérica cranial isolada. Enquanto a artéria mesentérica cranial foi ocluída por 45 minutos nos grupos G2 e G3, antes da anastomose, no grupo G1 a anastomose foi realizada sem esta lesão prévia. Em seguida $2 \mathrm{~mL}$ de azul de metileno 0,5\% foi instilado na cavidade peritoneal dos animais do grupo G3, $2 \mathrm{~mL}$ de solução salina isotônica na cavidade dos animais do grupo G2. Após a reperfusão uma enterectomia seguida de anastomose foi realizada. Os animais foram submetidos à eutanásia no $7 .^{\circ}$ dia após a operação, a cavidade abdominal foi examinada e um segmento intestinal que continha a anastomose foi ressecado. Este serviu para a medida de resistência e para exame anátomo-patológico. Resultados: Líquido livre ou abscessos foram raros. A análise da inflamação mostrou que o grupo submetido à isquemia sem azul de metileno apresentou maior score para células mononucleares $(\mathrm{p}=0,021)$ e tecido de granulação $(0,044)$. Não se observou diferença significante na análise do colágeno I e III. Conclusão: $\mathrm{O}$ azul de metileno não mostrou efeitos benéficos na cicatrização de anastomoses intestinais submetidas à isquemia e à reperfusão em ratos.

Descritores: Anastomose Cirúrgica. Cicatrização de Feridas. Isquemia. Intestino Delgado. Traumatismo por Reperfusão. Azul de Metileno. Ratos.

${ }^{1}$ Research performed at Post-Graduate Program of Surgery, Pontifical Catholic University of Paraná (PUC-PR), Brazil. 


\section{Introduction}

Acute mesenteric ischemia is a severe abdominal condition and has a high morbidity and mortality rate. It occurs after a sudden reduction in the flow of blood to the intestine and, gradually, leads to intestinal lesions of varying degrees of severity ${ }^{1,2,3}$. The incidence of this condition has increased substantially in the last decade ${ }^{1-4}$, mainly as a result of the increased number of elderly patients in the population whose health remains stable thanks to technological and therapeutic advances ${ }^{4}$.

Circulation can very often be restored without the need to carry out extensive resections of intestinal loops. Restoration of the oxygen supply to ischemic tissues is essential for tissue repair, as oxygen provides energy and removes toxic metabolites. However, paradoxically, reperfusion of ischemic tissues leads to subsequent inflammatory events that cause tissue lesions with consequences that may be worse than those caused by ischemia ${ }^{5,6}$.

The specific mechanism of tissue damage is still the subject of debate. In addition to the mucosal lesions themselves, an increase in vascular permeability and leukosequestration have also been reported ${ }^{7}$. Xanthine oxidase, a molybdenum protein, is a cytoplasmic enzyme known for its involvement in the catabolism of purines $^{8}$. The oxidation of hypoxanthine and xanthine to uric acid by xanthine oxidase is followed by reduction of molecular oxygen to superoxide, generating free oxygen radicals ${ }^{5,9}$. This reaction not only affects the intestine locally but also reaches other more distant organs, which may contribute to multiple organ failure ${ }^{10}$.

The local effect that ischemia-reperfusion has on intestinal anastomoses has been studied by various other authors. Healing has been shown to be worse in segments subjected to ischemiareperfusion insult ${ }^{11,12}$, because the inflammatory process normally caused by surgical trauma is exacerbated by ischemia-reperfusion. This results in an exaggerated inflammatory response, leads to collagenolysis in the area adjacent to the anastomosis and severely compromises healing ${ }^{11}$.

Various substances that prevent the formation of free radicals have been studied, including xanthine oxidase inhibitors. Alopurinol, the best-known xanthine oxidase inhibitor, has been proved to be an effective agent ${ }^{13,14}$. This purine analog competes with purine for the active site on the enzyme.

Methylene blue is another substance that could be used, as it has low toxicity, is soluble in water and is approved for use in humans ${ }^{15}$. There is a consensus that this substance is part of a new class of antioxidant drugs that inhibits free radical formation by competition, by acting as an alternative receptor site for electrons from xanthine oxidase ${ }^{16}$. Pairs of electrons from each enzymatic oxidation are transferred to methylene blue from the iron-sulfur center of xanthine oxidase, thus inhibiting the conversion of oxygen and the formation of superoxide radicals.

The objective of this study is to investigate the influence of methylene blue on the healing of intestinal anastomoses subjected to ischemia and reperfusion in rats.

\section{Methods}

This study was approved by the Ethics Committee for Animal Research of the Pontifical Catholic University of Paraná, in accordance with the Council for International Organizations of Medical Sciences under number 013/03.
Forty-five adult Wistar rats (Rattus norvegicus albinus, Rodentia mammalia) weighing between 250 and $400 \mathrm{~g}$ and between 100 and 150 days old were used in this experiment. The animals were separated into the following 3 groups of 15 rats each: group 1 (G1, control), group 2 (G2, ischemia without methylene blue) and group 3 (G3, ischemia with methylene blue).

The animals were not fed any solid food during the night prior to surgery, and a general anesthetic was administered intraperitoneally (ketamine at $60 \mathrm{mg} / \mathrm{kg}$ and xylazine at $7.5 \mathrm{mg} / \mathrm{kg}$ ). The operation consisted of a median incision followed by transection of an intestinal segment $20 \mathrm{~cm}$ below the pylorus, followed by termino-terminal anastomosis with a total of 8 separate, equidistant stitches using a 6-0 nylon monofilament suture.

In group 1 the anastomosis was performed without a prior ligature whereas in groups 2 and 3 (ischemia and reperfusion) a temporary delicate ligation of a segment of the cranial mesenteric artery was performed with porcine small intestine submucosa. After vascular occlusion in groups 2 and 3, a provisional laparorrhaphy was carried out to minimize intra-abdominal exposure. After 45 minutes - the time required for vascular ischemia - the animals'abdominal cavities in these groups were reopened. Immediately after the removal of the vascular occlusion, $2 \mathrm{~mL}$ of sterile $0.5 \%$ methylene blue were instilled intraperitoneally in group 2 (Figure 1), and $2 \mathrm{~mL}$ of saline solution instilled in the same way in group 3. After reperfusion had been confirmed by checking the pulse rate of the mesenteric artery, the intestinal anastomosis was carried out.

On the 7th day after the operation, the animals were sacrificed with a lethal dose of the anesthetic used in the surgery. The abdomen was accessed through the median incision scar that had been made previously and was examined for intraperitoneal fluid, peritoneal adhesions to the anastomosis and any other complications.

The adhesions were classified and graded by two observers in a blind study, according to the grades shown below:

- grade 0: absent

- grade I: present, affecting $1 / 4$ of the circumference of the anastomosis;

- grade II: present, affecting 2/4 of the circumference of the anastomosis;

- grade III: present, affecting 3/4 of the circumference of the anastomosis;

- grade IV: present, affecting 4/4 of the circumference of the anastomosis;

A segment of small intestine, approximately $4 \mathrm{~cm}$ long containing the anastomosis, was resected. The proximal end of the resected intestinal segment was tied around the air inlet with a double ligation using 3.0 cotton thread so that the air "nozzle" was inside the intestine and the oxygen could enter the lumen. The distal end of the intestine was sutured in a pouch to prevent the oxygen from escaping. The segment was then inflated with a constant oxygen flow of $1 \mathrm{~L} / \mathrm{min}$ through a catheter inserted at the proximal end. The second outlet was coupled to a mercury manometer, and the intraluminal pressure was recorded at the time of rupture, which was indicated by air bubbles coming out of the intestinal lumen.

The surgical specimen was then opened longitudinally along the antimesenteric border. The specimens were laid out on filter paper, immersed in numbered flasks and fixed in $10 \%$ buffered formalin. Four micrometer thick sections were cut and stained 
with hematoxylin-eosin (H.E.) and Sirius red.

The sections stained with H.E. were examined for polynuclear cells, edema, congestion, mononuclear cells, angiogenesis and fibroplasias. In the sections stained with Sirius red, collagen was quantified and classified.
Representative microscopic fields from the anastomosis area were examined and a numerical score was given to the findings for fibrosis, inflammatory reaction, edema, vascular congestion and granulation tissue, with negative scores for acute variables and positive ones for chronic variables (Table 1).

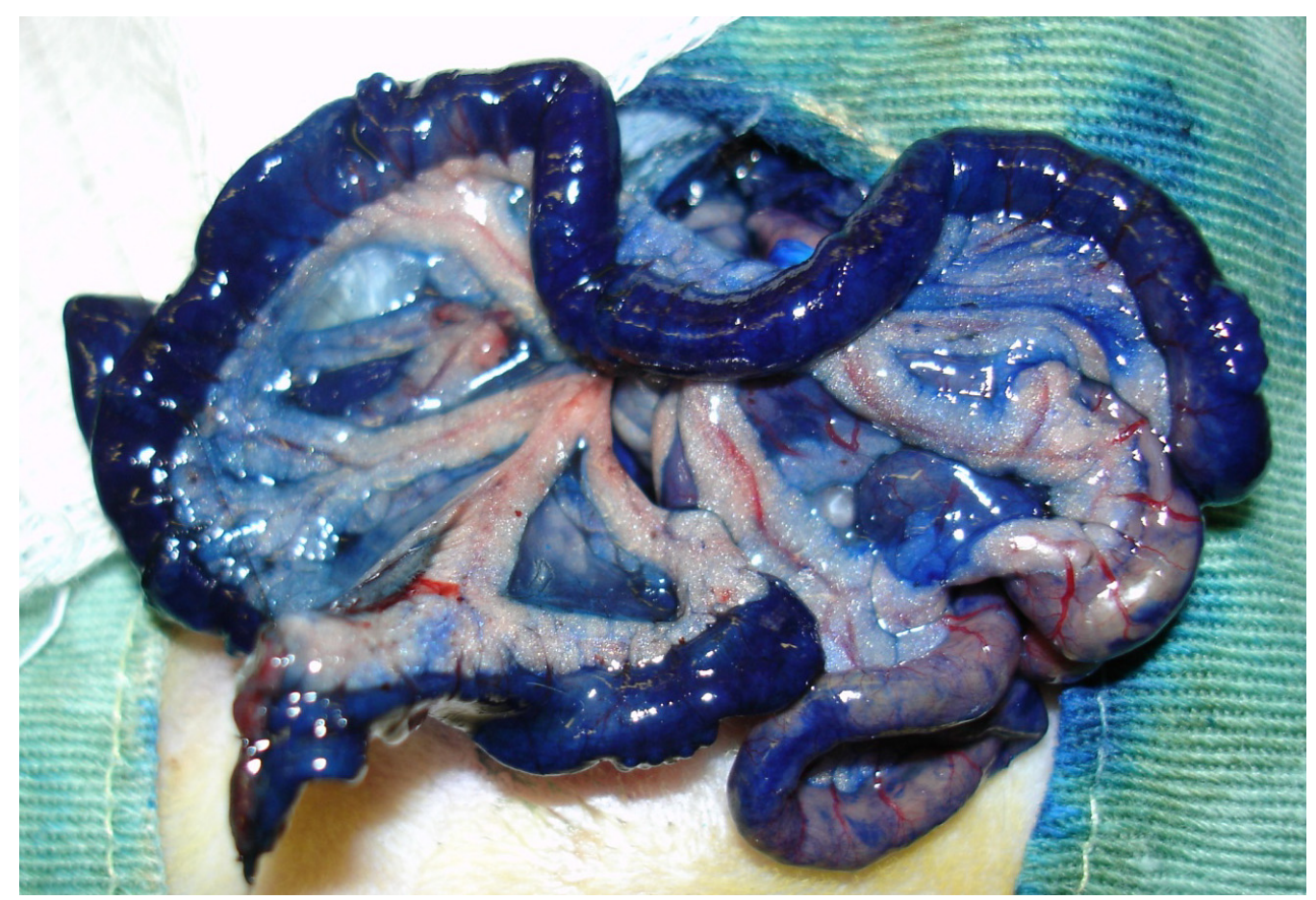

FIGURE 1 - Intestinal loops after injection of methylene blue and declamping

TABLE 1 - Variables used to establish the final inflammation score

\begin{tabular}{ccccc}
\hline $\begin{array}{c}\text { Inflammatory } \\
\text { process }\end{array}$ & Variable & Discrete & Moderate & Marked \\
\hline Acute - & Polynuclear cells* & -1 & -2 & -3 \\
\hline Chronic + & Edema & -1 & -2 & -3 \\
\hline & Congestion & -1 & -2 & -3 \\
\hline & Fononclear cells & 1 & 2 & 3 \\
\hline & Granulation tissue & 1 & 2 & 3 \\
\hline
\end{tabular}

*Analysis of the inflammatory cells:

Up to 50 cells in $1 / 4$ of a field under high magnification $(x 400)=1$

From 50 to 100 cells in $1 / 4$ of a field under high magnification $(x 400)=2$

More than 100 cells in $1 / 4$ of a field under high magnification $(x 400)=3$ 
The final score was the sum of all six variables. Positive results were considered to represent a predominantly chronic inflammatory response and negative results a predominantly acute inflammatory response.

The sections stained with Sirius red were used to assess the proportion of type I and type III collagen using cross-polarization, as described by Junqueira et al. ${ }^{17}$ Type I collagen fibers appeared orange-red when viewed with cross-polarized light, and type III collagen fibers appeared greenish.

Using a Zeiss optical microscope at 200X magnification, four areas from the anastomotic segment were selected. The images were captured with a video camera and processed with Image-Pro Plus imaging software. The percentages of type I and type III collagen were then measured.

The following statistical tests were used: one-way ANOVA to analyze the variance of independent samples; the parametric Student $\mathrm{t}$ test; the non-parametric Mann Whitney and Kruskal-Wallis tests (using the Primer of Biostatistics software); and the Fischer exact test (with the Epi Info program). A significance level of 5\% $(\mathrm{p}<0.05)$ was used.

\section{Results}

One animal died in the immediate postoperative period as a result of an accident with the anesthetic; two deaths occurred on postoperative days 4 and 5 in the ischemia group due to peritonitis following dehiscence of the anastomosis; and four deaths occurred in the methylene blue group on the $3 \mathrm{rd}$, 4th and 5th days, also as a result of peritonitis and dehiscence of the anastomosis. Tensile testing was hindered by the presence of fibrous adherences, making it difficult to prepare the samples and rendering many of them useless. The small number of viable samples thus available prevented a meaningful statistical analysis from being carried out.

\section{Macroscopic assessment}

The control group (1) had more odorless, colorless free fluid in the abdominal cavity than the ischemia group without methylene blue (2) $(\mathrm{p}=0.004)$ and the ischemia group with methylene blue (3) ( $p=0.007)$. Group 3 had more adhesions adjacent to the anastomosis than the control group (1) and the ischemia group without methylene blue $(2)(\mathrm{p}=0.008)$ (Table2). The average scores of the inflammation reaction are shown in the Figure 2.

TABLE 2 - Macroscopic evaluation of the study groups

\begin{tabular}{|c|c|c|c|c|c|c|c|c|}
\hline \multirow{3}{*}{ DATA } & \multirow{2}{*}{\multicolumn{2}{|c|}{$\begin{array}{c}\text { Control Group } \\
(n=14)\end{array}$}} & \multirow{2}{*}{\multicolumn{2}{|c|}{$\begin{array}{c}\text { Ischemia Group } \\
\text { (n=13) }\end{array}$}} & \multirow{2}{*}{\multicolumn{2}{|c|}{$\begin{array}{c}\text { Methylene Blue } \\
\text { Grup } \\
(n=11)\end{array}$}} & \multirow{2}{*}{\multicolumn{2}{|c|}{$\begin{array}{l}\text { TOTAL } \\
(n=38)\end{array}$}} \\
\hline & & & & & & & & \\
\hline & $\mathrm{N}^{0}$ & $\%$ & $\mathrm{~N}^{0}$ & $\%$ & $\mathrm{~N}^{0}$ & $\%$ & $\mathrm{~N}^{\mathrm{O}}$ & $\%$ \\
\hline \multicolumn{9}{|l|}{$\begin{array}{l}\text { ABDOMINAL } \\
\text { FLUID }\end{array}$} \\
\hline - $\quad$ No & 7 & 50.0 & 13 & 100.0 & 11 & 100.0 & 31 & 81.6 \\
\hline - Yes & 7 & 50.0 & - & - & - & - & 7 & 18.4 \\
\hline \multicolumn{9}{|l|}{ ADHESIONS } \\
\hline$\bullet \quad$ Grade 0 & 4 & 28.6 & - & - & - & - & 4 & 10.5 \\
\hline - Grade I & 6 & 42.9 & 6 & 46.1 & 4 & 36.4 & 16 & 42.1 \\
\hline - $\quad$ Grade II & 2 & 14.3 & 5 & 38.5 & 6 & 54.5 & 13 & 34.2 \\
\hline - $\quad$ Grade III & 1 & 7.1 & 2 & 15.4 & 1 & 9.1 & 4 & 10.5 \\
\hline - $\quad$ Grade IV & 1 & 7.1 & - & - & - & - & 1 & 2.7 \\
\hline
\end{tabular}




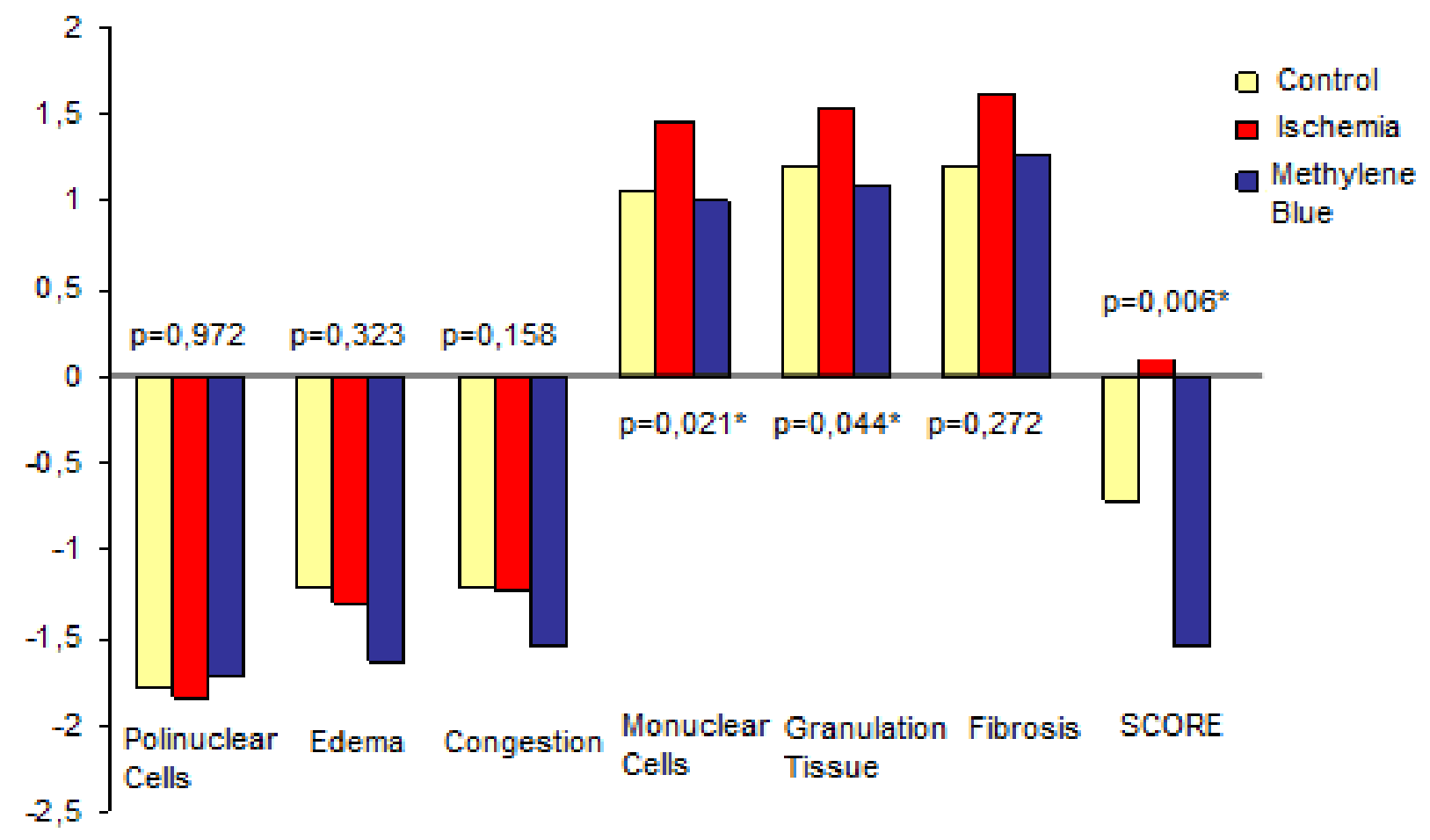

FIGURE 2 - Bar chart showing the mean values of the parameters used to evaluate inflammation for the three groups in the study Kruskal-Wallis.

(*) C x I: $\mathrm{p}=0.052 ; \mathrm{C} \times \mathrm{MB}: \mathrm{p}=0.375 ; \mathrm{I} \times \mathrm{MB}: \mathrm{p}=0.024$

$(* *)$ C x I: $p=0.087 ; \mathrm{C} \times \mathrm{MB}: \mathrm{p}=0.413$; I $\mathrm{x}$ MB: $\mathrm{p}=0.023$

$(* * *)$ C $\mathrm{I}: \mathrm{p}=0.0541 ; \mathrm{C} \times \mathrm{MB}: \mathrm{p}=0.034 ; \mathrm{I} \times \mathrm{MB}: \mathrm{p}=0.005$

The average scores for polynuclear cells for both the control group and the ischemia groups (with and without methylene blue) were moderate, with no statistically significant difference between them $(-1.79 \times-1.85 \times-1.73)(p=0.972)$.

The average scores for edema in both the control group and the ischemia group without methylene blue were -1.21 and 1.31 (discrete inflammation), respectively, and in the ischemia group with methylene blue the score was -1.64 (discrete to moderate inflammation). Even though the score was higher in the ischemia group with methylene blue, no statistically significant difference was observed $(\mathrm{p}=0.323)$.

The average scores for vascular congestion in both the control group and the ischemia group without methylene blue were -1.21 and -1.23 (discrete inflammation), respectively, and in the ischemia group with methylene blue the score was -1.55 (discrete to moderate inflammation). Even though the score was higher in the ischemia group with methylene blue, no statistically significant difference was observed $(\mathrm{p}=0.158)$.

The average scores for polynuclear cells in both the control group and the ischemia group with methylene blue were +1.07 and +1.00 (discrete inflammation), respectively, and in the ischemia group without methylene blue the score was +1.64 (discrete to moderate inflammation). The score was higher in the ischemia group without methylene blue, and this difference was found to be statistically significant $(\mathrm{p}=0.021)$.

The average scores for granulation tissue in both the control group and the ischemia group with methylene blue were +1.21 and +1.09 (discrete inflammation), respectively, and in the ischemia group without methylene blue the score was +1.54 (discrete to moderate inflammation). The score was higher in the ischemia group without methylene blue, and this difference was found to be statistically significant $(\mathrm{p}=0.044)$.

The average scores for fibrosis in both the control group and the ischemia group with methylene blue were +1.21 and +1.27 (discrete inflammation), respectively, and in the ischemia group without methylene blue the score was +1.62 (discrete to moderate inflammation). The score was higher in the ischemia group without methylene blue, but this difference was not statistically significant $(\mathrm{p}=0.272)$.

No statistically significant difference in the proportion of type I to type III collagen was observed for the three groups $(p=0,297)$. 


\section{Discussion}

Despite advances in modern medicine, the mortality rate among patients with intestinal ischemia is high and varies from 60 to $100 \%$ according to the cause of the ischemia and the associated diseases ${ }^{18}$.

The use of methylene blue has been described in the treatment of urinary tuberculosis, cyanide poisoning, metahemoglobinemia, nitrite poisoning, urinary tract infections ${ }^{16}$ and herbicide poisoning with Paraquat ${ }^{\circledR}{ }^{15}$.

It acts by competing with molecular oxygen for the electrons transferred by xanthine oxidase. Pairs of electrons from each oxidation are transferred to the methylene blue molecule. This transfer of electrons diverts the flow from the iron-sulfur center of the enzyme, where molecular oxygen is converted into superoxide radicals, reducing the production of these radicals ${ }^{15,16}$. Kelner et al. ${ }^{15}$, reviewing the mechanisms of action of methylene blue, observed that it could be used to inhibit the production of superoxides in ischemic tissues. Salaris et al. ${ }^{16}$, following up these observations, investigated the role of methylene blue as a potential inhibitor of superoxide production by xanthine oxidase. They suggested that methylene blue could diminish the effects of lesions following reperfusion, if pretreatment (before the ischemia) were provided so as to reduce the accumulation of hypoxanthine during the ischemia or if it were administered immediately after the ischemiareperfusion so as to inhibit superoxide production. They observed that this aromatic chemical compound is an effective antioxidant in ischemia-reperfusion.

Ischemia and reperfusion have a negative effect on the healing of intestinal anastomoses. In an experimental work, when animals with occlusion of the cranial mesenteric artery on its own were compared with another group with concomitant occlusion of collateral vessels, it failed to find any statistically significant difference in cicatrization ${ }^{19}$.

Various models of intestinal ischemia, with mortality rates varying from 8 to $80 \%$, have been used to perform occlusions of the cranial mesenteric artery for periods from 1 to 90 minutes ${ }^{11,12,19-27}$.

With regard to the vascular occlusion technique used in this work, a pilot study was initially carried out with 11 animals. Some of the animals were submitted to occlusion of the cranial mesenteric artery with a vascular clamp for 60 minutes at the point where it emerges and others for 45 minutes. However, none of the rats survived beyond the 2 nd day after the operation. As the objective of this study was to reach the 7 th postoperative day, we chose to use segmental ischemia for 45 minutes, thus enabling most of the animals to survive. Difficulties were encountered with the surgical instrument used to occlude the mesenteric vessel, which had caused local lesions in the pilot study. We chose porcine intestinal submucosa to temporarily occlude the vessel, and this proved an effective way temporarily obstructing the flow of blood without lesioning the vessel.

Megison et al. ${ }^{28}$ studied collateral circulation after occlusion of the cranial mesenteric artery and its effects on the severity of lesions following ischemia. They questioned the inconsistency of the relationship between mortality and the duration of arterial occlusion. The authors operated on groups of rats subjected to occlusion of the cranial mesenteric artery and collateral vessels. When only the cranial mesenteric artery was clamped, the average reduction in mesenteric blood flow was $83 \%$ and varied from 44 to $97 \%$ between individuals. But when the collateral vessels were also interrupted, the average reduction in blood flow was $97.8 \%$ and varied from 91 to $100 \%$ between individuals. They came to the following conclusions: (1) isolated occlusion of the cranial mesenteric artery does not reproduce ischemia and mortality and should not therefore be used to study mesenteric ischemia; (2) there is significant, variable collateral mesenteric blood flow leading to inconsistent results when isolated occlusion of the cranial mesenteric artery is used; (3) consistent and severe ischemia is achieved when collateral vessels are occluded together with the cranial mesenteric artery; (4) occlusion of both the cranial mesenteric artery and collateral vessels leads to mortality rates that are proportional to the duration of the ischemia.

Bergren et al. ${ }^{27}$, in a study of the effects of free radical scavengers in intestinal anastomoses after ischemia also used segmental clamping of $3 \mathrm{~cm}$ to $5 \mathrm{~cm}$ segments of mesenteric vessels. They concluded that the use of superoxide dismutase as a freeradical scavenger did not cause any significant change in the woundhealing process; however, postoperative mortality was equal to that of the control group and less than that of the group with ischemia that did not receive treatment.

In our pilot study, the animals subjected to occlusion of the cranial mesenteric artery at the point where it emerges did not survive for more than 48 hours after the operation. As the objective of the present study was to analyze the wound-healing process on the seventh postoperative day, we performed segmental ischemia of the branches of the cranial mesenteric artery to allow the animals to survive until the date on which they were to be sacrificed and to make the study viable.

A statistically significant difference was found in the free liquid in the abdominal cavity of the rats for the different groups operated on in the present study. The control group had a greater volume of liquid, but the liquid was colorless and odorless. The objective in analyzing this parameter was to establish whether any infection, as indicated by thick fluid with cell clumps and a purulent appearance, was present in the peritoneal cavity. No infection was in fact found.

Macroscopic analysis showed that adhesions adjacent to the anastomosis were more common in the group of rats subjected to ischemia with methylene blue; this difference was found to be statistically significant. A possible explanation for this finding is that the irritant action of methylene blue on the peritoneum interferes with the inflammatory process in the region of the anastomosis.

Ischemia-reperfusion promotes a systemic response mediated primarily by neutrophils, cytokines and free oxygen radicals $^{29}$. The effects of methylene blue on the prevention of pulmonary lesions due to ischemia-reperfusion reduced neutrophil se- 
questration in the histological analysis and a reduction in pulmonary edema ${ }^{30}$. On the prevention of intestinal and renal lesions following intestinal ischemia and reperfusion methylene blue does not play any role in protecting the organs examined ${ }^{31}$. This was one of the reasons for the present study, whose objective was to establish whether the positive effects of methylene blue could be observed in intestinal anastomosis. In the present study, the following parameters were used to assess inflammation by microscopy: polynuclear cells, edema, vascular congestion, mononuclear cells, granulation tissue and fibrosis.

No statistically significant differences were observed between the three study groups in terms of polynuclear cells, edema or vascular congestion.

The score for mononuclear cell count, however, was higher in the ischemia group without methylene blue (discrete to moderate inflammation) than in the other groups (discrete inflammation). It is noteworthy that the histological findings for the ischemia group with methylene blue were similar to those of the control group, possibly suggesting that methylene blue has a beneficial effect as an inhibitor.

There was a statistically significant difference between the score for granulation tissue for the ischemia group without methylene blue (discrete to moderate inflammation) and the scores for the ischemia group with methylene blue and the control group (discrete inflammation), a result similar to that for the analysis of mononuclear cells.

The scores for fibrosis followed the same pattern observed for mononuclear cells and granulation tissue, namely, a higher score for the ischemia group without methylene blue (discrete to moderate inflammation) than those for the ischemia group with methylene blue and the control group (discrete inflammation).

With regard to collagen concentration, it is known that the free oxygen radicals produced as a result of ischemia-reperfusion lead to collagenolysis ${ }^{33}$. Superoxide radicals derived from neutrophils in the region of the anastomosis may also contribute to collagenolysis $^{32,33}$. The use of antithrombin III prevents any adverse effects caused by this amino acid in colon anastomoses subjected to ischemia and reperfusion. The use of antithrombin III leads to a significantly higher collagen concentration in anastomoses in rats treated with this protein than in rats subjected to ischemia without $\mathrm{it}^{25}$.

Biondo-Simões et al. ${ }^{37}$ investigated the effects of intestinal ischemia-reperfusion on the healing of anastomoses of the small intestine. They compared the concentrations of collagen on postoperative days 3 and 7. On postoperative day 7 the control group had the highest collagen concentration and the group that had been subjected to ischemia for the longest time had the lowest value.

In our study there was no significant difference in type I or type III collagen levels between the three groups.

\section{Conclusion}

Methylene blue did not show beneficial effect on the healing of intestinal anastomoses subjected to ischemia and reperfusion in rats.

\section{References}

1. Kaleya RN, Boley SJ. Acute mesenteric ischaemia: an aggressive diagnostic and therapeutic approach. Can J Surg. 1992;35(6):613-23.

2. De Roos WK, Geelkerken RH, Van Bockel JH. Acute mesenteric embolism: an appeal for a pro-active diagnostic approach. Neth J Surg. 1990;42(4):110-2.

3. Kummerlen C, Seiler N, Galluser M, Gossé F; Knodgen B; Hasselmann M; Raul F. Polyamines and the recovery of intestinal morphology and function after ischemic damage in rats. Digestion. 1994;55(3):168-74.

4. Grace PA, Da Costa M, Quereshi A, Sheehan S, BurKe P, BouchierHayes D. An aggressive approach to acute superior mesenteric arterial ischemia. Eur J Vasc Surg. 1993;7(6):731-2.

5. Zimmerman BL, Granger DN. Reperfusion injury. Surg Clin North Am. 1992;72(1):65-83.

6. Parks DA, Granger DN. Contributions of ischemia and reperfusion to mucosal lesion formation. Am J Physiol. 1986;250(6 Pt 1):G749-53.

7. Galili Y, Bem-Abraham R, Weinbroum A, Marmur S, Laina A, Volman Y, Peer G, Szold O, Soffer D, Klausner J, Rabau M, Kluger Y. Methylene blue prevents pulmonary injury after intestinal ischemia-reperfusion. J Trauma. 1998;45(2);222:5.

8. Bray RC. Molybdenium iron-sulfur flavin hydrolases and related enzymes. In: Boyer RD. The enzymes. 3ed. Academic Press; 1975. p.229-419.

9. Lynch RE, Fridovich I. Effects of superoxid on the erythrocyte membrane. J Biol Chem. 1978;253(6):1838-45.

10. McCord JM. Oxigen-derived free radicals in postischemic injury. N Engl J Med. 1985;312(3):159-63.

11. Demirogullari B, Sönmez K, Türkyimaz Z, Ekingen G, Dursun A, Bor V, Turkozkan N, Basaklar AC, Kale N. Comparision of consequent small bowel anastomoses after transient ischemia: an experimental study in rats. J Pediatr Surg. 1998;33(1):91-3.

12. Kuzu MA, Köksoi C, Kale IT, Tanik A; Terzi C, Elhan AH. Reperfusion injury delays healing of intestinal anastomosis in a rat. Am J Surg. 1998;176(4):348-51.

13. Gupta PC, Matsushita M, Oda K, Nishikimi N, Sakurai T, Nimura Y. Attenuation of renal ischemia-reperfusion injury in rats by allopurinol and prostaglandin E-1. Eur Surg Res. 1998;30(2):102-7.

14. Albuquerque RG, Sanson Aj, Malangoni MA. Allopurinol protects enterocytes from hypoxia-induced apoptosis in vivo. J Trauma. 2002;53(3):415-20.

15. Kelner MJ, Bagnell R, Hale B, Alexander NM. Methylene blue competes with paraquat for reduction by flavo-enzimes resulting in decreased superoxide production in the presence of heme proteins. Arch Biochem Biophys. 1988;262(2):422-6.

16. Salaris SC, Babbs CF, Voorhees WD. Methylene blue as an inhibitor of superoxide generation by xantine-oxidase: a potential new drug for the attenuation of ischemia/reperfusion injury. Biochem Pharmacol. 1991;42(3):499-506.

17. Junqueira LCU, Cossermelli W, Brentani RR. Differential stain of collagen type I, II and III by sirius red and polarization microscopy. Arch Histol Jpn. 1979;41:267-74. 
18. Lock G. Acute mesenteric ischemia: classification, evaluation and therapy. Acta Gastroenterol Belg. 2002;65(4):220-5.

19. Kuzu MA, Tanik A, Kale IT, Aslar AK, Koksoy C, Terzi C. Effect of ischemia/ reperfusion as a systemic phenomenon on anastomotic healing in the left colon. World J Surg. 2000;24(8):990-4.

20. Haglind E, Haglund U, Lundgren O, Romanus M, Shersten T. Graded intestinal vascular obstruction.I. Description of an experimental shock model in the rat. Circ Shock. 1980;7(1):83-91.

21. Dalsing MC, Grosfeld JL, Schiffler MA, Vane DW; Hull M; Baehner RL; Weber TR. Superoxide dismutase: a celular protective enzyme in bowel ischemia. J Surg Res. 1983;34(6):589-96.

22. Boorstein JM, Ducey LJ, Cronenwett JL. Pharmacologic treatment of occlusive mesenteric ischemia in rats. J Surg Res. 1988;44(5):555-60.

23. Kologlu M, Yorganci K, Renda N, Sayek I. Effect of local and remote ischemia- reperfusion injury on healing of colonic anastomoses. Surgery. 2000;128(1):99-104.

24. Biondo-Simões MLP, Greca FH, Ioshii SO, Chin EWK, Kimura LY, Lemos MC. Efeitos da isquemia e reperfusão intestinal na cicatrização de anastomoses do intestino delgado- estudo experimental em ratos. Acta Cir Bras. 2001;16(supl 2):9-15.

25. Tekin K, Aytekin FO, Ozden A, Bilgihan A, Erdem E, Sungurtkin U, Guney Y. Antithrombin III prevents deleterious effects of remote ischemiareperfusion injury on healing of colonic anastomoses. Am J Surg. 2002;184(2):160-5.

26. Ponsky J, McCollister DM, Aszodi A, Grzonka R, Lee Ponsky. Effects of transient ischemia on the healing small bowel anastomosis. Am Surg. 1988;54(8):517-8
27. Bergren CT, Bodzin JH, Cortez JA. Improved survival using oxygen free radical scavengers in the presence of ischemic bowel anastomosis. Am Surg. 1988;54(6):333-6.

28. Megison SM, Horton JW, Chao H, Walker PB. A new model of intestinal ischemia in the rat. J Surg Res. 1990;49(2):168-73.

29. Witte MB, Barbul A. Repair of full-thikcness bowel injury. Crit Care Med. 2003;31(8 suppl):S538-46.

30. Greca FH, Souza Filho ZA, Gonçalves NM, Silva APG, Olandoski M, Mima WH, Mima HH. A influência do azul de metileno na prevenção da lesão pulmonar após isquemia- reperfusão intestinal. Acta Cir Bras. 2004;19(4):431-40.

31. Greca FH, Gonçalves NMFM, Souza Filho ZA, Noronha L, Silva RFKC, Rubin MR. The protective effect of methylene blue in lungs, small bowel and kidney after intestinal ischemia and reperfusion. Acta Cir Bras. 2008;23(2):149-56.

32. Hernandez LA, Grisham MB, Granger DN. A role for iron in oxidantmediated ischemic injury to intestinal microvasculature. Am J Physiol. 1987;253(1Pt 1):G49-53.

33. McGowan SE, Murray JJ. Direct effects of neutrophil oxidants on elastase-induced extracellular matrix proteolysis. Am Rev Respir Dis. 1987;135(6):1286-93.

34. Biondo-Simões MLP, Greca FH, Ioshii SO, Chin EWK, Kimura LY, Lemos MC. Efeitos da isquemia e reperfusão intestinal na cicatrização de anastomoses do intestino delgado- estudo experimental em ratos. Acta Cir Bras. 2001;16(Supl 2):9-15.
Conflict of interest: none Financial source: none

\section{Correspondence:}

Eron Fábio Miranda

Rua Prudente de Morais, 732/02

80430-220 Curitiba - PR Brazil

Phone: (55 41)3343-6459

eronfm@brturbo.com.br

\section{How to cite this article}

Miranda EF, Greca FH, Noronha L, Kotze LR, Rubin MR. The influence of methylene blue on the healing of intestinal anastomoses subjected to ischemia and reperfusion in rats. Acta Cir Bras. [serial on the Internet] 2010 Jan-Feb;25(1). Available from URL: http:// $\underline{\text { www.scielo.br/acb }}$ 